\title{
Commentary: Finding valor in discretion: Musings on contemporary therapy for the failing aortic homograft
}

\author{
Gopal Bhatnagar, MD, and Rakesh Suri, MD, DPhil
}

\footnotetext{
From the Department of Cardiac Surgery, Heart and Vascular Institute, Cleveland Clinic Abu Dhabi, Abu Dhabi, United Arab Emirates.

Disclosures: Authors have nothing to disclose with regard to commercial support.

Received for publication Dec 24, 2018; accepted for publication Dec 26, 2018; available ahead of print Feb 21, 2019

Address for reprints: Rakesh Suri, MD, DPhil, Department of Cardiac Surgery, Cleveland Clinic Abu Dhabi, Heart and Vascular Institute, PO Box 112412, Abu Dhabi, United Arab Emirates (E-mail: rakesh.m.suri@ gmail.com orsurir@ccf.org).

J Thorac Cardiovasc Surg 2019;158:390-1

$0022-5223 / \$ 36.00$

Copyright (c) 2019 by The American Association for Thoracic Surgery

https://doi.org/10.1016/j.jtcvs.2018.12.084
}

The better part of valour is discretion; in the which better part I have saved my life.

-William Shakespeare, Henry IV, Part I

Act V, scene 4, lines 136-8

Since the first homograft by Dr Ross ${ }^{1}$ in 1962, there have been varying levels of enthusiasm for use of the technique around the world. In their article in this issue of the Journal, "Repeat Aortic Valve Replacement for Failing Aortic Root Homograft," the Mayo Clinic group of Sedeek and colleagues ${ }^{2}$ report on 54 consecutive patients undergoing reoperation between 2000 and 2018, with transcatheter aortic valve replacement (TAVR) performed in 11 cases and surgical aortic valve replacement in 40. Subsequent to 2014, $80 \%$ of patients were treated with TAVR. The surgical reoperations were not straightforward; cardiac injury on sternal reentry occurred in $38 \%$, redo root replacement was required in $75 \%$, concomitant operations were performed in $58 \%$, and Cabrol modification was performed in $17 \%$. On the other hand, vascular injury occurred in $36 \%$ of patients in the TAVR group versus $15 \%$ in the surgical aortic valve replacement group. Procedural mortalities were $8 \%$ in the surgical aortic valve replacement group and $1 \%$ in the TAVR group, with mortalities during the follow-up period of $30 \%$ and $18 \%$, respectively.

Although a surgical mortality of $8 \%$ is commendable in such a complex reoperative setting, most surgeons are unlikely to have this breadth of surgical experience. This article is valuable in drawing attention to the potential for improvement in early results with TAVR, likely as a result of the avoidance of the often encountered calcification of the homograft requiring complete excision, reconstruction, and reimplantation of the calcified coronary ostium, all of which further press surgical skill. ${ }^{3,4}$ The development of TAVR and sutureless valve technology may alleviate the need for such extensive surgery without compromising short-term and, possibly, long-term survival. Previous publications have shown TAVR to be used successfully in

\section{References} 404-8.

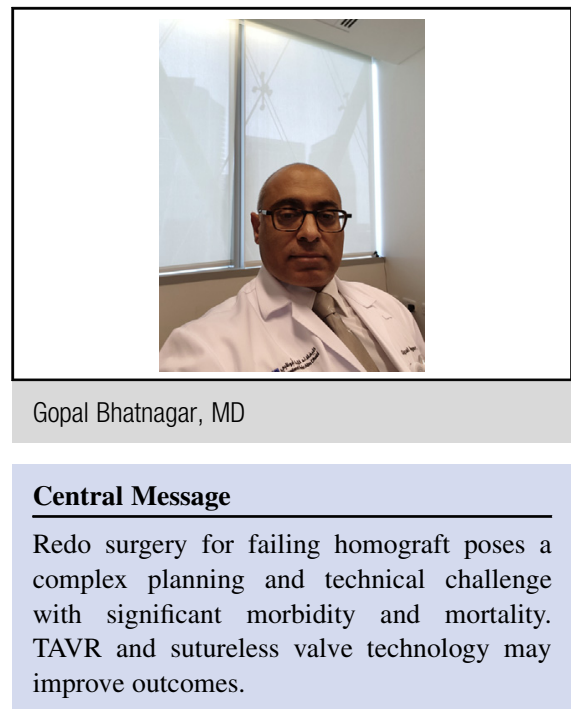

See Article page 378 .

stentless root failures from either valve stenosis or regurgitation. ${ }^{5}$ The analysis of homograft root geometry adds to our understanding of a cicatrized homograft root and will assist others in planning TAVR prosthesis sizing and positioning, with a recommendation to overfill slightly. Another option exists for patients in whom TAVR is not considered to be feasible, which is not addressed in the article - the use of rapidly deployable sutureless valves. ${ }^{6,7}$ Although extensive root reconstruction is feasible in experienced hands, consideration of TAVR as a means of addressing the failing aortic homograft, along with judicious use of sutureless valve implantation when a surgical approach is mandated, may, for the better part, save lives.

1. Ross DN. Homograft replacement of the aortic valve. Lancet. 1962;2:487.

2. Sedeek AF, Greason KL, Nkomo VT, Eleid MF, Maltais S, Williamson EE, et al. Repeat aortic valve replacement for failing aortic root homograft. J Thorac Cardiovasc Surg. 2019;158:378-85.e2.

3. Joudinaud TM, Baron F, Raffoul R, Pagis B, Vergnat M, Parisot C, et al. Redo aortic root surgery for failure of an aortic homograft is a major technical challenge. Eur J Cardiothorac Surg. 2008;33:989-94.

4. Kowert A, Vogt F, Beiras-Fernandez A, Reichart B, Kilian E. Outcome after homograft redo operation in aortic position. Eur J Cardiothorac Surg. 2012;41:

5. Bapat V, Attia R, Redwood S, Hancock J, Wilson K, Young C, et al. Use of transcatheter heart valves for a valve-in-valve implantation in patients with degenerated aortic bioprosthesis: technical considerations and results. J Thorac Cardiovasc Surg. 2012;144:1372-9; discussion 1379-80. 
6. Danesi TH, Minniti G, Cresce GD, Favaro A, Magagna P, Auriemma S, et al. Redo after failure of aortic homografts with a rapid deployment valve. Ann Thorac Surg. 2016;102:e281-2.
7. Folesani G, Calcara G, Minniti G, Polesel E. Reoperation for aortic homograft fail ure using an Edwards Intuity valve. Interact Cardiovasc Thorac Surg. 2016;22: $378-80$. 